\begin{tabular}{|c|c|}
\hline & $\begin{array}{l}\text { International Journal of Trend in Scientific } \\
\text { Research and Development (IJTSRD) }\end{array}$ \\
\hline $\begin{array}{lll} & \\
0\end{array}$ & International Open Access Journal \\
\hline 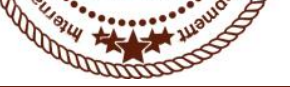 & ISSN No: $2456-6470 \mid$ www.ijtsrd.com | Volume - 2 | Issue -4 \\
\hline
\end{tabular}

\title{
Contributions of the National Programme on Food Security (NPFS) on Household Food Security in Enugu State
}

\author{
${ }^{1}$ Onuoha, Onyekachi Chibueze; ${ }^{2}$ Onugu, Charles Uchenna; ${ }^{3}$ Edoga, Juliet Chinenye \\ ${ }^{1} \mathrm{M} . \mathrm{Sc},{ }^{2} \mathrm{Ph} . \mathrm{D},{ }^{3} \mathrm{PGD}, \mathrm{B} . \mathrm{Sc}$ \\ ${ }^{1,3}$ Department of Cooperative Economics and Management, ${ }^{2}$ Department of Agricultural Economics, \\ ${ }^{1,2,3}$ Nnamdi Azikiwe University, Awka
}

Abstract-- In Nigeria, two-third of the population lives in food poverty, and poor access to the means of supporting rural development being among the causative factors. Consequently, food security which goes with food self-sufficiency and sustainability is still elusive. Agriculture remains a key component of the Nigeria economy. The Government has made very frantic efforts to ensure food security by introducing a number of programmes including the National Programme on Food Security however, the extent to which it has moved in the direction of ensuring food security is unknown. This study therefore sought to determine the contributions of the National Programme on Food Security on household food security in Enugu State. A hypothesis was formulated to guide the study. A well-structured questionnaire was validated and used to collect relevant information from 450 respondents who were randomly selected from three Local Government Areas which were hitherto used as sites for the National Food Security Programme in Enugu State. Findings indicated that the National programme has helped farmers to improve in some areas by providing loans, seedlings, machines, and these led to an increase in household food security. Recommendations were made at strengthening efforts on food security.

Key words-- Food Security, National, Programme

\section{INTRODUCTION}

Food security has generated a lot of concern all over the world. A household is considered food secured when its occupants do not live in hunger or fear of starvation (FAO 2001)[1]. Food security exists when all people, at all times, have physical, social and economic access to sufficient, safe and nutritious food to meet their dietary needs and food preferences for an active and healthy life (Idachaba, 2006)[2]. Food security for a household means access by all members at all times to enough food for an active, healthy life. According to Wibberley (2005)[3], food security at household, village, national and international levels require: availability of adequate quantity and quality of locally-grown agricultural produces; accessibility of supplies for urban and land-remote areas (food attainable and affordable); appreciation of the close link between nutrition and health for work and enjoyment; avoidance of undue risk through livelihood vulnerability, hazard and shock.

In Nigeria, two-third of the population lives in food poverty, and poor access to the means of supporting rural development being among the causative factors. Consequently, in Nigeria, food security which goes with food self-sufficiency and sustainability is still elusive. Agriculture remains a key component of the Nigeria economy; currently contributing about $40 \%$ of the Nigeria GDP and employing about $70 \%$ of the active population. The sector has however significantly underperformed its potential (NFSP, 2012)[4]. Nigeria has 79 million hectares of fertile land, however, only 32 million hectares $(46 \%)$ of these are cultivated. More than $90 \%$ of agricultural output is accounted for by with less than 2 hectares under cropping. Typical farm sizes range from 0.5 hectares in the south to 4 hectares in the north (NFSP, 2012).

Supply of agricultural output has also been generally sub-optimal. Nigeria fertilizer consumption at $7 \mathrm{~kg} / \mathrm{hectare}$ is one of the lowest in sub-Sahara Africa. Less than $10 \%$ of irrigable land is under irrigation. Farmers have limited access to credit and the existing 
extension services are grossly inadequate. There is currently 1 extension worker to 25,000 farm families in Nigeria compared to best practice of 1 to 500-1000. Mechanized assistance is also grossly inadequate. There are only about 30,000 tractors for all 14 million farming groups/families in Nigeria. On the processing front, Nigeria loses significant value of between $15 \%$ $40 \%$ due to its inability to process most of its agricultural produce (NFSP, 2012).

Nigeria, in spite of her great potentials, has been experiencing food shortage and serious protein deficiency for her teaming population since the sixties. This has caused a continuous rise in the country's import bill on food items over the years as a result of decreasing domestic production. Nigeria currently faces serious food and agricultural problems, manifesting in the declining per capita food production, growing food importation and accelerating ecological degradation ENADEP (2008)[5]. This is in spite of the fact that the country has the human and natural resources to produce in sufficient quantity the kind of food needed.

In a bid to solve the problem of food production in the country, the Federal Government of Nigeria has initiated different programmes over the years. For instance, on May 21st, 1976, the Obasanjo led Military Government launched the Operation Feed the Nation (OFN) (ENADEP, 2008). The aim of this programme was to make the nation self-sufficient in the basic needs of the people. There was also the Green Revolution launched in 1979. Besides the Green Revolution of the Shehu Shagari Administration, another practical step taken to address the growing poverty and malnutrition problems among Nigerians was the National Directorate of Employment of the Babangida's Administration. The directorate had various programmes which included National Youth Empowerment and Vocational Skills Development, especially in livestock and poultry production (ENADEP, 2008). There was also the Directorate of Food, Roads and Rural Infrastructure (DFRRI) established in 1986. Under this programme, people were mobilized and organized to participate actively in production activities which would ensure abundance of food in terms of protein, availability of housing, rural health and nutrition, manpower development, and rural industrialization. The Family Economic Advancement Programme (FEAP) was launched in 1997 by the then wife of the Head of State, Mrs. Abacha as a welfare scheme. Most of these programmes have been abandoned at some point in time due to change in government and in certain cases, perceived ineffectiveness.

All the above mentioned programmes and a number of other ones because of one reason or the other, failed to meet target of self-sufficiency in food production (Nyam, 2005)[6]. As a result, and as a first step towards the Millennium Development goals target of reducing by half the number of hungry people by 2015, the Federal Government of Nigeria operated a pilot project of the National Programme on Food Security (NPFS) in 3 sites of Kano State. Based on the successful experience, a five year nationwide National Programme for Food Security (NPFS) was launched in 2001 with the objective to increase and stabilize food production rapidly and sustainably through the wide spread dissemination of improved technologies and management practices in areas with high potential, and to create an economic and social environment conducive to food production as well as reaching some 30,000 farming families in each selected areas (NFSP, 2012). The extent of success or otherwise of the National Programme on Food Security on its mandate and on ensuring food security is yet to be x-rayed.

\section{OBJECTIVES OF THE STUDY}

The broad objective of this study was to access the contributions of NPFS on the living standard of farmer's household food security in the study area. The specific objectives were to:

1. Determine the Farmers access to supportactivities of NPFS in the study area;

2. Assess the state of household food security before and after the NPFS programme in the study area;

3. Determine the effect of NPFS programme on the farmer's household food security based on availability, accessibility, quality and stability of food in Enugu state.

\section{HYPOTHESIS OF THE STUDY}

Ho - Support activities of NPFS have not significantly improved farmers' household food security in Enugu State.

\section{National Programme on Food Security (NPFS)}

The NPFS is one of government's efforts towards boosting agricultural production. It does this by extending relevant financial and material assistance to the rural farmers. Under the NPFS farmers are expected to organize themselves into various enterprise cooperative groups before they are eligible 
to access the NPFS benefits. The pilot phase was launched in November, 2001. The project was fully financed by the Nigerian Government. The NPFS funded three production/demonstration sites in each state and one in the federal capital territory. According to Onugha (2008)[7], the implementation of the NPFS resulted to a rapid improvement in food production, food security at household and community levels and rural poverty alleviation in concerned project areas. Based on the success of the programme, the Federal government decided on its expansion for a period of five years. This led to tripling the number of the demonstration sites. However, the facilitators of the project are of the view that the NPFS phase was more viable than the NPFS. According to them, more farmers benefitted from the loan and they were more motivated.

The NPFS objectives as outlined by Onugha (2008) are to:

1. Improve household food security and incomes through increase in agricultural productivity, diversification and sustainable use of natural resources;

2. Enhance food security of consume through improved availability of and access to a variety of foods;

3. Increase income of producers through valueadded primary processing and more efficient marketing.

4. Enhancing farmers and consumers access to support services such as extension, credit, nutrition and health education; and Table 1: Support activities of NPFS to its members
5. Foster the participation of the poorer section of the rural population including women, youths and other vulnerable groups in the development of the community.

\section{RESEARCH METHOD}

The study adopted a descriptive survey research design. The population of the study is made up of all the Cooperative farmers in the 9 Local Government areas in the Enugu state used as sites by the Federal Government of Nigeria (NFSP). The Local Government Areas include; Adani Uzo-Uwani L.G.A, Amagunze Nkanu East L.G.A, Nenwe Aninri L.G.A, Agu Ukehe Igbo-Etiti L.G.A, Obollo Etiti Udenue L.G.A, Eha-Amufu Isi Uzo L.G.A, Inyi-Oji River L.G.A, Obeagu Enugu South L.G.A and Obinofia Ndiagu Ezeagu L.G.A. However only three Local Government Areas were randomly selected which are Amagunze Nkanu East, Eha Amufu Isi Uzo, and Igbo-Etiti. One hundred and fifty farmers each were randomly selected from each of the three Local Government Areas ensuring spread of the communities in the Local Government Areas. Therefore a total of 450 farmers constituted the sample of the study. The main instrument for the collection of primary data was the questionnaire specifically designed for this study. Data obtained were analyzed using descriptive statistics including mean and standard deviation. The hypothesis was tested using one sample T-test.

\section{Data Presentation and Analysis}

\begin{tabular}{lllll}
\hline S/N & Factors & $\begin{array}{c}\text { Mean } \\
(\mathbf{x})\end{array}$ & $\begin{array}{l}\text { Standard } \\
\text { Deviation }\end{array}$ & Decision \\
\hline 1 & Provision of loan to members & 4.5 & 0.876 & Very High \\
2 & Encouraging members to do things in common like sharing & 3.67 & 0.879 & High \\
& help among themselves in terms of farming activities & & & \\
3 & Assists members to acquire poultry, processing house etc & 3.87 & 0.987 & High \\
4 & Encouraging members to save & 3.53 & 0.792 & High \\
5 & Procurement of farm inputs & 1.87 & 1.048 & Low \\
6 & Provision of basic rural infrastructures e.g. borehole & 4.2 & 0.908 & High \\
7 & Processing/value addition of agricultural products. & 2.6 & 1.083 & Low \\
8 & Enhancing their social welfare & 3.1 & 1.204 & High \\
9 & Improving members standard of living & 2.3 & 1.098 & Low \\
10 & Helping members to acquire entrepreneurial skills & 3.8 & 1.004 & High \\
\hline
\end{tabular}




\section{Source: Field Survey, May, 2016.}

Table 1 shows the support activities NPFS provides for its members. Members agreed that the Support activities which the respondents received which were high include; provision of loan to members, encouraging members to do things in common, assists members to acquire poultry, processing house, encouraging members to save, provision of basic rural infrastructures (borehole), enhancing their social welfare, helping members to acquire entrepreneurial skills.

Table 2: The Influence of NFPS on Availability of Household Food Security

\begin{tabular}{|c|c|c|c|c|c|c|c|}
\hline \multirow[t]{2}{*}{$\mathrm{S} / \mathrm{N}$} & \multirow[t]{2}{*}{ Food items } & \multicolumn{3}{|c|}{ Before joining the NPFS } & \multicolumn{3}{|c|}{ After joining the NPFS } \\
\hline & & Mean & $\begin{array}{l}\text { Standard } \\
\text { Deviation }\end{array}$ & Decision & Mean & $\begin{array}{l}\text { Standard } \\
\text { Deviation }\end{array}$ & Decision \\
\hline 1 & Cassava & 3.5 & 0.897 & Available & 4.3 & 0.823 & Available \\
\hline 2 & Garri \& Soup & 3.3 & 0.972 & Available & 3.7 & 0.971 & Available \\
\hline 3 & Yams/potatoes & 2.7 & 1.348 & Not Available & 3.0 & 1.789 & Available \\
\hline 4 & Rice & 1.2 & 0.954 & Not Available & 2.3 & 1.970 & Not Available \\
\hline 5 & Beans & & 0.782 & Not Available & 3.2 & 0.786 & Available \\
\hline 6 & Maize & 3.5 & 0.771 & Available & 4.2 & 0.781 & Available \\
\hline 7 & Fish & 1.0 & 1.029 & Not Available & 3.4 & 0.987 & Available \\
\hline 8 & Meat (beef) & 2.3 & 1.009 & Not Available & 3.1 & 1.160 & Available \\
\hline 9 & Chicken & 2.4 & $1.07 \overline{9}$ & Nôt Available & $3.1 \mathrm{C}$ & 1.192 & Available \\
\hline 10 & Egg & 2.2 & 0.972 & Not Available & 4.2 & 0.890 & Available \\
\hline 11 & Kanda & 2.1 & 0.812 & Not Available & 4.2 & 0.828 & Available \\
\hline 12 & Vegetables & 3.4 & 0.689 & Available & 4.1 & 0.901 & Available \\
\hline 13 & $\begin{array}{l}\text { Minerals (Oil, } \\
\text { salt, onions etc }\end{array}$ & 2.9 & 0.738 & Not Available & 4.0 & & Available \\
\hline 14 & Moi-moi & 1.5 & 0.98 & Not Available & 3.0 & 0.917 & Available \\
\hline 15 & Bread & 2.1 & 0.789 & Not Available & 3.1 & 1.028 & Available \\
\hline 16 & Cereals & 1.0 & 0.789 & Not Available & 2.1 & 0.678 & Not Available \\
\hline 17 & Noodles & 1.2 & 0.789 & Not Available & 2.3 & 0.910 & Not Available \\
\hline 18 & Milk & 2.2 & 0.972 & Not Available & 3.1 & 0.872 & Available \\
\hline 19 & $\begin{array}{l}\text { Fruits (pear, } \\
\text { pineapple, } \\
\text { paw-paw) }\end{array}$ & 3.6 & 0.892 & Available & 4.4 & 0.952 & Available \\
\hline \multirow[t]{2}{*}{20} & $\begin{array}{l}\text { Soaking garri } \\
\& \text { sugar/salt }\end{array}$ & 3.8 & 0.672 & Available & 2.1 & 0.865 & \\
\hline & $\begin{array}{l}\text { Grade Mean } \\
(\mathrm{x})\end{array}$ & 2.80 & & Not Available & 3.51 & & Available \\
\hline
\end{tabular}

\section{Source: Field Survey, May, 2016.}

Table 4.2 shows the influence of NPFS on availability of household food security of members. With a grand mean (x) of 2.80 , the respondents unanimously agreed that there was no availability of food (quantity) before 
International Journal of Trend in Scientific Research and Development (IJTSRD) ISSN: 2456-6470

joining NPFS. On the other hand, with 3.51 the there was an improvement in the availability of respondent agreed that there has been availability of household food security.

food (quantity) since joining the NPFS indicated that

Table 3: The Influence of the NPFS on Accessibility of Household Food Security.

\begin{tabular}{|c|c|c|c|c|c|c|c|}
\hline \multirow[t]{2}{*}{$\mathbf{S} / \mathbf{N}$} & \multirow[t]{2}{*}{ Food items } & \multicolumn{3}{|c|}{ Before joining the NPFS } & \multicolumn{3}{|c|}{ After joining the NPFS } \\
\hline & & Mean & $\begin{array}{l}\text { Standard } \\
\text { Deviation }\end{array}$ & Decision & Mean & $\begin{array}{l}\text { Standard } \\
\text { Deviation }\end{array}$ & Decision \\
\hline 1 & Cassava & 3.3 & 0.980 & Accessible & 4.2 & 0.908 & Accessible \\
\hline 2 & Garri \& Soup & 3.3 & 0.897 & Accessible & 3.7 & 0.906 & Accessible \\
\hline 3 & Yams/potatoes & 2.7 & 1.086 & Not accessible & 3.0 & 0.898 & Accessible \\
\hline 4 & Rice & 1.2 & 1.234 & Not accessible & 3.3 & 1.190 & Not accessible \\
\hline 5 & Beans & 1.5 & 1.216 & Not accessible & 3.2 & 0.908 & Accessible \\
\hline 6 & Maize & & 0.890 & Accessible & 4.2 & 0.876 & Accessible \\
\hline 7 & Fish & & 1.108 & Not accessible & 3.4 & 0.781 & Accessible \\
\hline 8 & Meat (beef) & 1.3 & 1.091 & Not accessible & 3.1 & 0.971 & Accessible \\
\hline 9 & Chicken & 4 & 0.869 & Not accessible & 3.1 & 0.895 & Accessible \\
\hline 10 & Egg & 2.2 & 1.092 & Not accessible & 4.2 & 1.090 & Accessible \\
\hline 11 & Kanda & 2.1 & 1.098 & Not accessible & 4.2 & 0.921 & Accessible \\
\hline 12 & $\begin{array}{l}\text { Vegetables } \\
\text { scent leave, etc }\end{array}$ & 3.4 & 0.827 & $\begin{array}{l}\text { Accessible } \\
\text { arch and }\end{array}$ & 4.1 & 1.867 & Accessible \\
\hline 13 & $\begin{array}{l}\text { Minerals (Oil, salt, } \\
\text { onions etc }\end{array}$ & 2.9 & 1.027 & Not accessible & 4.0 & 1.007 & Accessible \\
\hline 14 & Moi-moi & 5 & 1.095 & Not accessible & 3.0 & & Accessible \\
\hline 15 & Bread & & 1.054 & Not accessible & 5.1 & 0.879 & Accessible \\
\hline 16 & Cereals & 1.0 & 1.067 & cessible & 2.1 & 0.893 & Not accessible \\
\hline 17 & Noodles & & & & & 0.993 & Not accessible \\
\hline 18 & Milk & 2.2 & 0.956 & Not accessible & 3.1 & 0.894 & Accessible \\
\hline 19 & $\begin{array}{l}\text { Fruits (pear, } \\
\text { pineapple, paw- } \\
\text { paw, orange etc) }\end{array}$ & 3.1 & 0.901 & Accessible & 4.0 & 0.932 & Accessible \\
\hline \multirow[t]{2}{*}{20} & $\begin{array}{l}\text { Soaking garri \& } \\
\text { sugar/salt }\end{array}$ & 3.6 & 0.981 & Accessible & 3.1 & 0.908 & Not accessible \\
\hline & Grand Mean (x) & 2.50 & & $\begin{array}{l}\text { Not } \\
\text { Available }\end{array}$ & 3.42 & & Available \\
\hline
\end{tabular}

Source: Field Survey, May, 2016.

Table 3 shows the influence of NPFS on the accessibility of household food security. The result revealed that the respondents were not able to access the household food security before joining NPFS with the grand mean of 2.50. It also showed the grand mean of 3.32 after joining the NPFS which is a 
International Journal of Trend in Scientific Research and Development (IJTSRD) ISSN: 2456-6470 positive change and means that there is an security. improvement in the accessibility of household food

Table 4: The Influence of NPFS on the Quality of Household Food Security

\begin{tabular}{|c|c|c|c|c|c|c|c|}
\hline \multirow[t]{2}{*}{$\mathbf{S} / \mathbf{N}$} & \multirow[t]{2}{*}{ Food items } & \multicolumn{3}{|c|}{ Before joining the NPFS } & \multicolumn{3}{|c|}{ After joining the NPFS } \\
\hline & & Mean & Std. D & Decision & Mean & Std. D & Decision \\
\hline 1 & $\begin{array}{l}\text { Carbohydrate (cassava, } \\
\text { rice, yam, bread, potato, } \\
\text { wheat, Mazie/corn, etc) }\end{array}$ & 3.1 & 0.991 & Often & 3.8 & 0.891 & Often \\
\hline 2 & $\begin{array}{l}\text { Protein (Beans, meat, } \\
\text { fish, egg, moi-moi, } \\
\text { cheese, milk, bread fruirt } \\
\text { etc) }\end{array}$ & 2.5 & 1.091 & Not often & 3.3 & 0.928 & Often \\
\hline 3 & $\begin{array}{l}\text { Vegetables/minerals } \\
\text { (salad, tomatoes, car } \\
\text { peas, salt etc) }\end{array}$ & & 953 & & & 0.891 & Often \\
\hline 4 & $\begin{array}{l}\text { Fats and Oil (oil, butter } \\
\text { added to food or use for } \\
\text { cooking) }\end{array}$ & 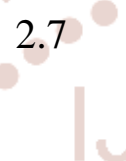 & 0.910 . & 1) & & 89 & Often \\
\hline 5 & $\begin{array}{l}\text { Roughages (tigher-nuts, } \\
\text { peanuts, etc) }\end{array}$ & 2.0 & 0.890 & Not Often & .1 & & Often \\
\hline 6 & $\begin{array}{l}\text { Cereals (bread, noodles, } \\
\text { biscuits, cookies or any } \\
\text { other food made from } \\
\text { wheat grain/flour, rice, } \\
\text { maize, barley etc) }\end{array}$ & 1.5 & 1.201 & Not Often & 5 & & Not Often \\
\hline 7 & $\begin{array}{l}\text { Fruits (apple, pineapple, } \\
\text { oranges, banana, pea, } \\
\text { watermelon etc) }\end{array}$ & 3.3 & 091 & Not Often & & 0.994 & Often \\
\hline 8 & $\begin{array}{l}\text { Others (soaking garri and } \\
\text { sugar/salt, kanda etc) }\end{array}$ & 2.4 & 101 & & & 1.004 & Often \\
\hline & Grand Mean & 2.51 & & Not often & 3.52 & & Often \\
\hline
\end{tabular}

Source: Field Survey, May, 2016.

Table 4.4 shows the influence of NPFS on the quality joining the NPFS. This result implies that there has of household food security of the agricultural been an improvement in the quality of household food cooperative members. The result showed a grand security of the respondent since joining the NPFS. mean of 2.51 before joining NPFS and 3.52 after

Table 5: The Influence of NPFS on the Stability of Household Food Security

\begin{tabular}{llllllll}
\hline S/N & Food items & \multicolumn{2}{c}{ Before joining the NPFS } & \multicolumn{2}{c}{ After joining the NPFS } \\
& & Mean & $\begin{array}{l}\text { Std. } \\
\text { Decision }\end{array}$ & N & Mean & Decision \\
& & D & & & & \\
\hline 1 & Cassava & 2.3 & 1.098 & Not Stable & 75 & 3.2 & Stable \\
\hline
\end{tabular}






Source: Field Survey, May, 2016.

Table 4.5 shows that the influence of the NPFS on the stability of household food security. The result shows grand mean of 2.12 before joining the NPFS and 3.20 after joining the NPFS. This revealed that there has been an improvement in the stability of household food security of the respondents.

\section{TEST OF HYPOTHESIS}

Ho - Support activities of NPFS have not significantly improved farmers' household activities food security in Enugu State.

Table 6: Summary of T-test (One-Sample Test)

\begin{tabular}{lllll}
\hline & T & DF & $\begin{array}{l}\text { Significant } \\
\text { (2failed) }\end{array}$ & Mean Difference \\
\hline $\begin{array}{l}\text { Support Activities } \\
\text { Of NPFS }\end{array}$ & 95.701 & 74 & .000 & 3.344 \\
\hline
\end{tabular}

Source: Field Survey, May, 2016. 
The table above reveals that the support activities of NPFS are significant at 0.05 relative to their effect on farmers' household food security. Therefore the null hypothesis was rejected while the alternate hypothesis was accepted which is that the support activities of NPFS have significantly improved farmers' household activities on food security in Enugu State.

\section{Summary of Findings}

After a thorough investigation and analysis of data generated from this research work the following findings were made; a farmer must be a member of a cooperative group before he is eligible to benefit from the NPFS. In order words, under the NPFS scheme, farmers are encouraged to form and register themselves as cooperative groups.

The research showed the support activities NPFS provides for its members. Members agreed that the support activities they received include; provision of loan to members, encouraging members to do things in common, assists member to acquire poetry, processing house, encouraging members to save, provision of basic rural infrastructures (borehole), enhancing their social welfare, helping members to acquire entrepreneurial skills. It also showed the influence of NPFS on availability of household food security of members. With a grand mean of 2.23 , the respondents agreed that there was no availability of food (quantity) before joining NPFS. On the other hand, with a mean of 3.51 the respondents agreed that there has been availability of food (quantity) since joining the NPFS, which indicates that there was an improvement in the availability of household food security.

The study also showed the influence of NPFS on the accessibility of household food security. The result revealed (with the grand mean of 2.02) that the respondents were not able to access the household food security before joining NPFS. It also showed the grand mean of 3.32 which is a positive change and means that there was an improvement in the accessibility of household food security. The result revealed a grand mean of 2.51 before joining NPFS and 3.52 after joining the NPFS. This result implies that there has been an improvement in the quality of household food security of the respondent since joining the NPFS. There was influence of the NPFS on the stability of household food security. This was revealed in a grand mean of 2.12 before joining the NSPFS and 3.20 after joining the NPFS. This indicated that there has been an improvement in the stability of household food security of the respondents.

\section{CONCLUSION}

Despite the problems associated with the NPFS, the researcher found that the programme has a significant effect on household food security. Farmers in the various NPFS demonstration sites have benefitted from the programme and have been able to increase household food security; as such the effort made by the government through the NPFS is not a wasted one.

\section{RECOMMENDATIONS}

Nevertheless, a lot more still needs to be done for the impact of the NPFS to be felt so as to prevent the fate of other previous programmes from befalling it. It is therefore based on this that the researcher makes the following recommendations;

1. The NPFS should be expanded. This should be in the form of establishing more demonstration sites in each state. These sites should be established in farming areas.

2. Intensive seminars and workshops should be organized for farmers on the need for formation of cooperatives. Cooperative education should be imparted on them. This should be targeted at educating the farmers on the benefits of cooperatives.

3. The facilitators of this programme should be motivated.

4. The government should provide subsidies on the farm inputs.

5. Proper monitoring to ensure that the credit given out are channeled into agricultural uses and to make sure that it gets to the targeted people.

6. Tractors should be provided to motivate farmers more specially the youth.

7. The NPFS services should be made more available, accessible, quality and adequate.

\section{References}

[1] FAO, (2001), Perspective Study on Agriculture Development in the in the Shellian Countries, Vol. 3

[2] Idachaba, F.S. (2006), Strategic and Policies for Food Security and Economic Development In Nigeria, Lagos: CBN

[3] Wibberley E.J (2005) Oil and Agriculture: Frameworks and farmers for food security. Paper presented at the annual lecture organized by the 
International Journal of Trend in Scientific Research and Development (IJTSRD) ISSN: 2456-6470

centre for food and agricultural strategy. University of Agriculture, Makurdi.

[4] NFSP (2012), National Food Security Programme of the Federal Republic of Nigeria

[5] ENADEP (2008), Enugu State Agricultural Development Programme Newsletter Vol. 1, Number 1.

[6] Nyam, T.T. (2005), The Concept and Philosophy of the Special Programme for Food Security
Paper, Presented at the Site Level, Sensitization Workshop on Concept and Philosophy of the Special Programme for Food Security held at Makurdi, Otukpo and Katsina Ala Sites. March 16-20, 2005.

[7] Onugha, J.O. (2008); The cooperative movement and Cooperation of farmers in the realization of Food Security Objectives. (Unpublished paper)

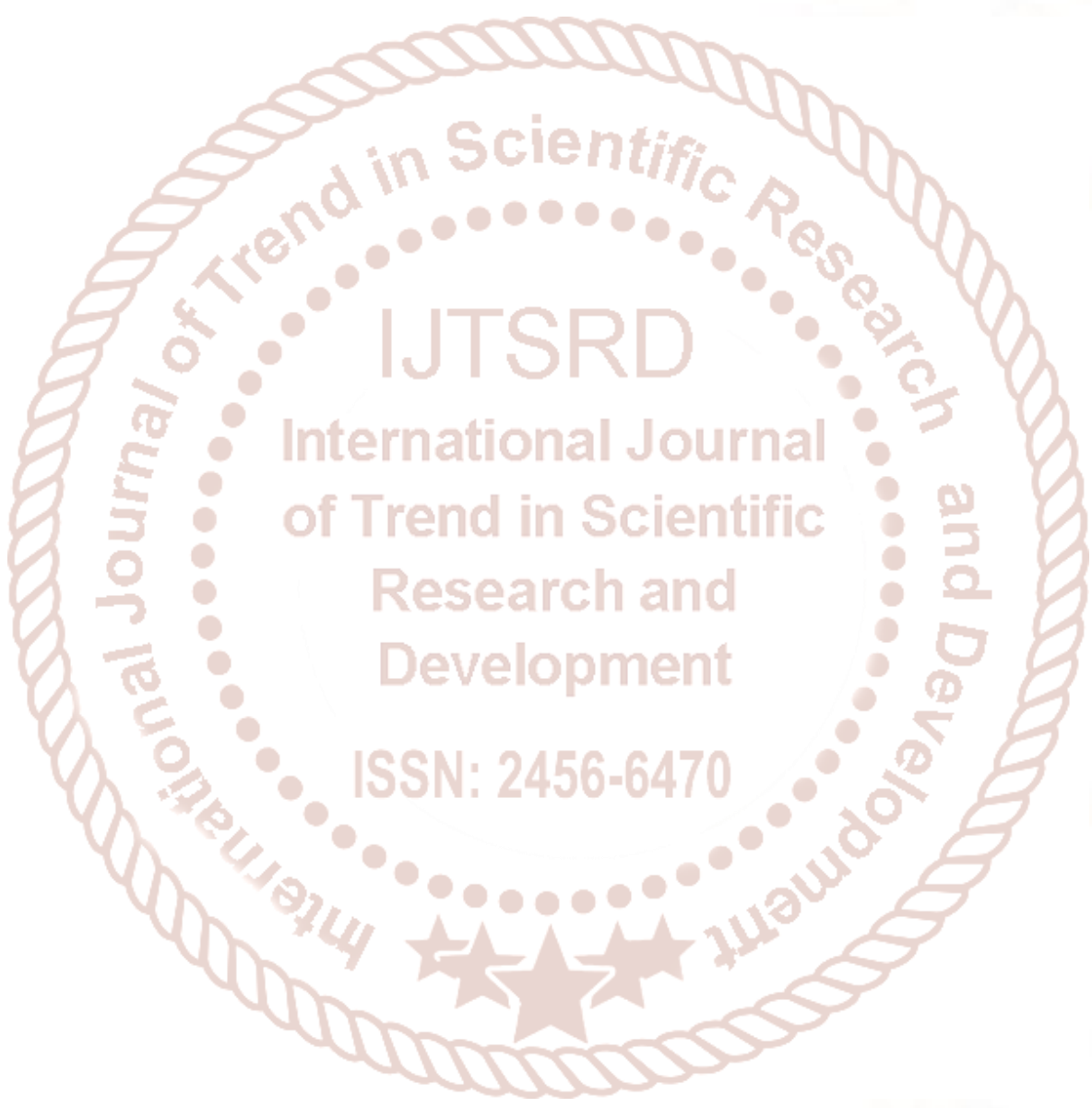

